\title{
Research, Productivity, and Pressures on Faculty in an Era of Disruptive Change
}

\author{
Danny Anderson, Dean, College of Liberal Arts \& Sciences, \\ University of Kansas
}

\begin{abstract}
1 round 2009 and 2010, we began to use a new term as we looked at the future of higher education: the "new normal." During the Great Recession of 2008, 1 - 1 state support for public higher education declined. Institutions cut programs, reorganized schools, and reprioritized initiatives to protect their core mission. At national meetings in 2009 and 2010, chancellors, presidents, provosts, and deans exchanged stories of local tragedies and coping strategies. At the same time, they began to imagine new ways to steward higher education resources. Leaders from every public institution can probably tell their own versions of this tale.
\end{abstract}

By these same years of 2009 and 2010, we also had developed a new relationship with technology. MySpace and Facebook gave a new meaning to social networks. GoogleBooks and GoogleMaps redefined information networks. Twitter convened new online publics. And the 2007 launch of the iPhone followed by other smart phones created a new experience of mobile networks (Jones 18-38).

Harvard business professor Clayton Christensen and others have characterized this convergence of economic pressures and technological change as an unprecedented era of disruption. In summer 2014, The Economist featured the topic of higher education change on its cover with the lead, "Creative Destruction: Reinventing the University" (June 28-July 4, 2014). About the same time, in The New Yorker, Harvard history professor Jill Lepore questioned Christensen's model, especially when applied to higher education. At the 2014 Merrill Research Retreat, Sally Mason, president of the
University of Iowa, framed the issue differently. She pointed out that public higher education has frequently operated under disruptive conditions of changing social and political expectations, and we should not be surprised that today we face another wave of changing expectations. I add to this conversation my concern for capturing at least portions of the faculty point of view: How faculty members experience and respond to the calls for change and the opportunity to reimagine their roles in the university.

The factors driving change converge in the everyday life of the tenured or tenure-track faculty at public research universities. Their careers are a juggling act combining research, teaching, and outreach under conditions of increasing constraint and unique opportunity. Nicholas Lemann, dean emeritus of Columbia University's Graduate School of Journalism, suggests that throughout the late $19^{\text {th }}$ and $20^{\text {th }}$ centuries the ideal of mass higher ed- 
ucation and the American research university were able to "flourish in tandem." Today, however, the political and social expectations have shifted. External stakeholders seek accountability, transparency, metrics, and rankings focused on universities as "skills-conferring, teaching-centric institutions." In contrast, writes Lemann, "...most of the senior leaders of universities believe that the institutions' core mission is research."

From the faculty point of view, these tensions create confusing and frustrating situations. Faculty members juggle many different balls striving to respond to multiple, competing priorities. On the one hand, faculty are asked to place a greater emphasis on students by increasing success as measured by retention, progression, and graduation measures, as well as implement a variety of "high touch" practices to achieve these goals. Faculty are also aware of the institutional bottom line: in tuition-dependent institutions, financial stability corresponds to student enrollment. On the other hand, for research universities, rankings depend on research productivity as measured by a variety of metrics: publications, citations, external funding, and highly prestigious national and international awards. Outstanding faculty make strides to excel as teachers and mentors, to stand out as researchers, and, in an age when the role of the research university is poorly understood by the general public, to participate in community engagement and outreach activities. These are all excellent goals. And it is important to note that the role of the tenured or tenure-track faculty appointment is vulnerable, especially in the way that public higher education relies on the use of contingent or adjunct faculty not on the tenure track and that all faculty roles are subject to increasing scrutiny. The faculty career is one of increasing anxiety and tension as they are asked to juggle additional balls to enable the enterprise to adapt to rapidly changing conditions.

There are many different surveys and assessments in higher education, yet not a common reference point for broadly benchmarking and tracking faculty work satisfaction on the tenure-track. The Chronicle of Higher Education annual survey, "Great Colleges to Work for in 2014," includes an article by Audrey Williams June, "The Uncertain Future of Academic Work." June notes the pace of change in academic work conditions, measurements of faculty productivity, cost containment practices, and expanding reliance on part-time or temporary faculty. There is a mismatch between institutional goals of quality instruction and institutional commitment among the professoriate. Jeffrey Williams, also in The Chronicle of Higher Education, describes the situation as "the great stratification" created by increasing specialization of "the faculty member" into "a multiple being, of many types, tasks, and positions." In summer 2014, the American Council on Education's Presidential Innovation Lab released a white paper, "Unbundling Versus Designing Faculty Roles." Whereas faculty members may think of themselves or their careers in terms of the "single provider," the faculty role is today subject to "the differentiation of tasks and services" that may be distributed "among multiple providers and individuals" (1). The faculty role can be and is being unbundled. Although 
"[u]nbundling does not have to have a negative impact," the white paper notes that "historically it has been implemented without being carefully designed" (2). These touch points of rapid change, rising productivity pressures, stratification, and unbundling create a context for considering broadly the data from surveys like the Collaborative on Academic Careers in Higher Education (COACHE) at Harvard University's Graduate School of Education. For example, noting that mid-career associate professors report the lowest satisfaction rate among faculty, that such dissatisfaction grows the longer the faculty member remains in rank, and that such dissatisfaction affects women and minority faculty members in greater numbers, COACHE director Kiernan R. Matthews provides data-informed advice for supporting mid-career faculty. Or to state Matthews' proposal differently, we must become intentional in listening to faculty voices and we must become intentional in designing faculty careers for the future.

Within the context of employee satisfaction, the 2010 Gallup Survey, "State of the American Workplace," provides an interesting framework for thinking about how we might categorize the challenges for supporting faculty to ensure our success in higher education. Administered about the time of the Great Recession of 2008, the survey notes that there are about one hundred million fulltime employees in the United States, and rather than satisfaction vs. dissatisfaction, the survey uses response data to group employees by their level of engagement with the workplace. About $28 \%$ of the respondents are "engaged employees." They care about change, want to see good things happen, and want to help the organization move forward. In the next group, about $53 \%$ are individuals who are "not engaged" with their work. They are not actively disruptive but they don't know or care about the mission. Finally, there were $19 \%$ of the individuals responding who were considered to be "actively disengaged." They don't like the change that is occurring and they want to see it stopped. They resist. This distribution curve of almost 30\% engaged, 50\% not engaged or on the fence, and $20 \%$ disengaged and resisting may not seem too distant from faculty reactions on our campuses during the same period as the Gallup survey. Jim Clifton, CEO of Gallup, in The Coming Jobs War, notes that "the most powerful behavioral lever" for increasing performance and productivity in the workplace is "increasing the number of employees who are engaged" (112).

With mounting challenges, shifting social expectations, redefinitions of the role of the professoriate, increasing calls for productivity metrics, scarce resources, and an increased pressure for boards, presidents, and provosts to exercise greater top-down decision-making to drive agile change, we need to focus on the role of our faculty and opportunities to increase their engagement. We need to develop effective leadership strategies if they, and by extension the universities where they work, are going to succeed. I have dwelled on the many contextual factors that affect our present moment, because understanding them is essential for developing our best plans as university leaders. All university presidents and chancellors, provosts, vice chancellors for 
research, and deans can enable their faculty and strengthen their research universities by adopting and adapting three key strategies to fit our unique institutional cultures.

Strategy \#1: Communicate lasersharp focus regarding vision and goals. Faculty members seek to understand where the institution is heading and why that is the best direction. Faculty engagement and commitment are inspired by the larger vision of where the organization is headed and why this destination is essential to the university's identity, success, and distinctive core competency. After such a vision is identified and communicated, there is the equally important communication challenge of ensuring that individual faculty members understand their roles and contributions.

At the level of the larger "why" and "where," confusing goals, unconvincing or uninspiring rationales, or multiple top priorities will create the sense of faculty members being asked to juggle too many balls. Shifting priorities and unexpected new goals, in the name of agility and responsiveness, will likely be experienced like a curve ball thrown into the juggling act.

Clarity of focus includes a clear understanding of individual faculty roles and contributions to the goals. If the faculty engagement distribution mirrors the Gallup survey of U.S. employee engagement, the top 30\% support change. But this top 30\% will become frustrated as they strive to fulfill their $40 \%$ teaching, $40 \%$ research, and $20 \%$ service performance expectation hearing one semester that research productivity is the top priority, another that student retention and graduation is the top priority, and yet another semester that metrics for rankings are the top priority. And when the top $30 \%$ of engaged faculty become frustrated, the next $50 \%$ of those not yet engaged or on the fence become much harder to reach and convince to commit to institutional excellence. This then is likely to create an amplifier that magnifies the voice of the $20 \%$ who actively resist change.

Communication strategies must recognize the multiplicity of the faculty: both the different strengths of individual faculty members to contribute uniquely to different aspects of the collective goals, and the changing arc of faculty careers that may allow individuals to develop different strengths over the course of a career. While there may be collective goals related to retention, graduation rates, student learning, pedagogical innovation, course redesign, curriculum change, technology in the classroom, assessment, increased publication and citation counts, more grant dollars, and greater recognition with highly prestigious awards (to name just some of the many balls we are juggling), individual faculty members will contribute to these goals in different ways, taking a greater lead in one area rather than another, but seldom taking the lead in all. Our faculty evaluation processes, performance expectations, and especially our communication about change all need to acknowledge that an individual faculty member cannot and is not expected to do it all. He or she may need to set one or two of the balls on the ground, while juggling others with greater concentration and skill. Because department chairs directly relay central 
administrative goals to faculty, it is essential to aid them in this communication challenge with clear priorities and consistent talking points; support for effectively using departmental talent is essential.

Strategy \#2: Construct conditions that motivate. As the academic career becomes more complex, the external motivations of carrots-and-sticks are not sufficient for inspiring engagement. Journalist Daniel Pink draws upon social science research in his book Drive: The Surprising Truth About What Motivates $U$ s to note that in the workplace carrots-and-sticks tend "to encourage short-term thinking at the expense of the long view" (48). Derived from $19^{\text {th }}$-century management technology based in compliance and control (86), a carrot-and-stick approach is more effective for routine tasks that "aren't very interesting and don't demand much creative thinking" (60). Motivation, however, leverages employee engagement by recognizing autonomy, mastery, and purpose.

- Autonomy, not to be confused with independence, means self-direction toward accomplishing a goal; it can often involve a team.

- Mastery emphasizes deep engagement with the process of accomplishing the goal: "the desire to get better and better at something that matters" (109), which is often characterized as the state of "flow" defined by psychologist Mihaly Csikszentmihalyi.

- Purpose links autonomy and mastery: "The most deeply motivated people-not to mention those who are most productive and satisfied- hitch their desires to a cause larger than themselves" (131).

Pink provides numerous examples of business organizations that are drawing upon these research-based strategies to improve employee morale and increase productivity. And he emphasizes that these practices do not undermine accountability. This motivation-driven philosophy "presumes that people want to be accountable-and that making sure they have control over their task, their time, their technique, and their team is the most effective pathway to that destination" (105).

Although academic freedom, research opportunities, and teaching choices would seem to make the university highly receptive to motivation-focused leadership practices, contextual forces are pulling in the other direction. Transparency, accountability, and performance metrics are key characteristics of public higher education in the 2010s. State legislatures and institutional governing boards increasingly seek to use these yardsticks for performance-based institutional funding; usually these efforts seek to accomplish a specific social agenda. Similarly, presidents, provosts, deans, and chairs may create internal performance metrics as the starting point for change. During a period of fiscal peril, like the post-2008 recession period, it is not surprising that legislatures, boards, presidents, and provosts increasingly rely upon top-down decision making to ensure the health of their universities. Risky times demand rapid responses. At the same time, returning to my emphasis on the faculty point of view, the incentives for getting on board with new plans 
and initiatives and the extrinsic motivators employed to generated faculty buyin are usually more characteristic of $19^{\text {th }}$ century management for compliance, control, and counting. The unexplored path is leadership by intrinsic motivation to increase professional engagement and productivity.

More broadly, there remains a tension between intrinsic faculty motivations and the extrinsic carrots available to drive faculty behavior. Metrics and efficiencies can be powerful plot points in the story we tell to represent the impact that universities have to benefit society, but they are not sufficient to intrinsically motivate faculty to achieve the excellence we seek in teaching, research, and service to our world. We need accountability and metrics, and we need them to be meaningful and supportive of the intrinsic motivations that increase engagement and productivity. Accountability and metrics frame the story of faculty success; accountability and metrics that do not resonate with the faculty will not force success or create cultural change. Restraint on extrinsic motivation and careful listening to faculty needs to attend to ways we can support intrinsic motivation and build new paths to lasting institutional transformation.

Strategy \#3: Cultivate faculty engagement over the entire arc of a changing career. We repeatedly say in higher education, "A great faculty makes a great university." Because of this principle, we devote resources and energy to searches and hiring. We strive to broaden perspectives and strengthen our dialogues through diversity. We invest in developing and retaining faculty talent. Yet higher education drops two very important balls in this part of the juggling routine. First, as COACHE surveys indicate, there is predictable variation in faculty engagement over a career as punctuated by promotions in rank and intensified by years in rank. Many resources support faculty in their early career to reach tenure and promotion to associate professor. The path from associate to full professor, however, has less structure and more room for wandering. Kiernan $R$. Matthews describes the associate professor "let-down":

Along with tenure comes an increased teaching load, greater expectations for service and advising, a more competitive market for grants, and the disappearance of mentoring programs that supported them as early-career faculty. In light of recent attention on "student success," these faculty are now being asked to add to their expectations for research excellence the new requirements to track student progression course by course, even week by week.

The toll of these obligations is heavier on women and faculty of color who, given their fewer numbers at this rank (in many disciplines), are asked to serve more, advise more, show up more-and not just for their department and the university, but for their discipline too. (1)

Because of this mid-career slump, I speculatively wonder about the Gallup engagement distribution curve, wondering how an individual faculty member may move from engaged to not engaged and even to disengaged and resisting at different points in a career.

Looking at the characteristics of faculty relationships with the university may lend some insight into this dynamic. As Nicholas Lemann notes in "The Soul of the Research University," faculty employment is unique: "Most people work 
for their employers. Faculty members at research universities work for their disciplines." We reinforce this unstated tension between loyalty to the university and loyalty to the discipline through many mechanisms that privilege and reward loyalty to the discipline, not least of which is the basic process of promotion and tenure review.

Both Matthews and Lemann make specific proposals that would address these challenges and create new opportunities for engagement over the arc of a faculty career. Matthews identifies an excellent range of practices that make visible the stages of a career and create programs for building conditions of loyalty to the institution. Lemann in turn notes that when research careers are "more oriented toward the institution" where they take place "and less toward the discipline," there are many benefits such as new opportunities for institutional alliances, internal research and teaching collaborations, and a rethinking of promotion and tenure incentives. One of the most striking features of faculty presentations at the Merrill Retreat, in contrast to a national conference based on disciplinary specializations, is the sense of belonging and pride in one's home institution. Repeatedly faculty members take pride in telling the story not of "research in the abstract" but of the way that their specific university enabled them to accomplish certain goals as a research faculty member. By focusing on the full arc of the faculty career and intentionally designing strategies to sustain faculty members for the long game, we can strengthen our institutions and strengthen faculty engagement.
In conclusion, these three strategies exemplify practices in a research university that create the opportunity to lead like researchers. With clarity of vision, conditions that motivate, and cultivation of faculty careers over the life span, these strategies call upon presidents, chancellors, provosts, and deans to lead as genuine collaborators with faculty in the reinvention of the university during an era of disruption. These strategies create opportunities for leadership experiments, to identify best practices and bright spots that can inspire the $50 \%$ not engaged to join the $30 \%$ of engaged employees who care about change and want the university to thrive. As Sally Mason noted, it is urgent and important for university leaders to convey optimism about our collective ability to make the best of all opportunities and to see our challenges as opportunities. The "new normal" and our new technologies have created many opportunities, and we must have optimism about our creativity, insight, and drive to take full advantage of the circumstances. Engagement and optimism can energize each other. The intentionality realized in these strategies will strengthen the university community and honor the principle that "A great faculty makes a great university."

\section{Works Cited}

American Council on Education Presidential Innovation Lab. "Unbundling Versus Bundling Faculty Roles." White Papers, July 2014. http://www.acenet.edu/newsroom/Documents/Unbundling-VersusDesigning-Faculty-Roles.pdf

Christensen, Clayton M. The Innovator's Dilemma. 1997. New York: Harper Business Essentials, 2003. 
Christensen, Clayton M. and Henry J. Eyring. The Innovative University: Changing the DNA of Higher Education from the Inside Out. San Francisco: Josey-Bass, 2011.

Clifton, Jim. The Coming Jobs War. New York: Gallup Press, 2011.

Gallup. "State of the American Workplace 2008-2010." http://www.gallup.com/services/177077/state-american-workplace2008-2010-pdf.aspx

Jones, Steven E. The Emergence of the Digital Humanities. New York: Routledge, 2014.

June, Audrey Williams. "The Uncertain Future of Academic Work." The Chronicle of Higher Education Survey of Great Colleges to Work for 2014 July 21, 2014. http://chronicle.com/article/The-Uncertain-Futureof/147755/

Lemann, Nicholas. "The Soul of the Research University." The Chronicle of Higher Education Review 28 April 2014. http://chronicle.com/article/The-Soul-of-the-Research/146155/
Mason, Sally. "Planning for Future Research in Public Universities in Uncertain Times." Keynote address. Merrill Research Retreat, July 17, 2014, Nebraska City, Nebraska.

Matthews, Kiernan R. "Perspectives on MidCareer Faculty and Advice for Supporting Them." Collaborative on Academic Careers in Higher Education, Harvard University Graduate School of Education. July 2014. http://isites.harvard.edu/fs/docs/icb.topic1023643.files//C OACHE Mathews MidcareerFaculty 20140721.pdf

Pink, Daniel H. Drive: The Surprising Truth About What Motivates Us. New York: Riverhead Books, 2009.

Williams, Jeffrey J. “The Great Stratification." The Chronicle of Higher Education Review December 2, 2013. http://chronicle.com/article/The-Great-Stratification/143285/ 